\title{
A FAILURE TO TRANSFORM METAZOAN SOMATIC CELLS BY DNA
}

\author{
F. S. BILLETT, L. HAMILTON and D. R. NEWTH \\ Deportment of Biology, Middlesex Hospitol Medical School
}

\section{INTRODUCTION}

Received 21.xi.63

BACTERIAL transformation and transduction have provoked a number of attempts to achieve DNA mediated genetic change in the cells of higher organisms. Some of these (see e.g. Bearn and Kirby, 1959; Astaurov et al., I96o; Beatty and Billett, I96I) have produced no evidence for biological activity of homologous or heterologous extracted DNA, and we think it likely that many other negative findings have not been published. Other attempts have produced evidence that DNA can be mutagenic, though without suggesting the specificity that accompanies the incorporation occurring during transformation (see e.g. Fahmy and Fahmy, 196I). Yet others have provided evidence of specific change, notably those of Benoit et al. (1957, 1958), after the administration of homologous DNA to young birds, and of Kraus (1961) and Szybalska and Szybalski (1962) after treatment of mammalian somatic cells in culture.

Benoit $e t$ al. originally injected DNA extracted from Khaki Campbell ducks into Pekin ducklings. The recipients grew into animals which had donor-type characteristics which were also reproduced in their offspring. This seemed to constitute a prima facie case for genetic transformation involving both somatic and germ-line cells. The results of this experiment have not proved capable of repetition (Benoit $e t$ al., 1960), and its original design and execution made it less than decisive in many ways. Thus the DNA used was so prepared and so treated that had it been bacterial in origin it would have lost nearly all its transforming activity; the recipient animals were of unknown genetic provenance; the differences between donor and recipient animals are not at all well understood genetically; experimental controls treated, for example, with heterologous DNA, were lacking. It consequently seemed to us desirable to perform an experiment of the same general kind as that of Benoit et al., but less open to these criticisms, and using, if possible, target cells of embryonic, or, at least, developmentally active, character in order that the expression of any genetic change in the somatic cells of the treated generation might be made easier to detect.

\section{GENETIC AND MORPHOGENETIC PROPERTIES OF THE TEST-SYSTEM}

We chose to use as a test-system cells of the white race of the axolotl (Ambystoma mexicanum). These carry a double dose of the autosomal 
recessive gene $d$, whose genetics was established by Haecker (1907) and whose morphogenetics have been extensively studied especially by Harrison (1935), DuShane (1939), Baltzer (1947), Dalton (1950) and Church (1955). The gene has full penetrance, fairly constant expression, and the three genotypes appear to be equally viable under laboratory conditions. Animals of $+/+$ or $+/ d$ constitution are indistinguishable phenotypically and are, from some time before they are half-grown, so darkly pigmented as to be nearly black. Animals of $d / d$ genotype are white, but are not true albinos since they have some mature melanocytes. These, so far as the skin is concerned, are almost confined to the dorsal and dorso-lateral parts of the body, and even here are less numerous than in wild-type animals.

The phenotype of $d / d$ animals does not, rather surprisingly, spring from any known distinction of their melanoblasts. These behave in just the same manner as $+/ d$ or $+1+$ ones on transplantation or explantation. Indeed $d / d$ melanoblasts substituted for $+/+$ ones in a $+1+$ embryo provide their host with as full a complement of melanocytes as it would normally enjoy. The gene expresses itself through the tissue environment of the melanoblasts and it is this that governs the extent to which they migrate, the numbers which will form melanin, and probably their mitotic activity. The eggs of the three genotypes are indistinguishable in appearance at laying; the black and white phenotypes only become distinct when the first melanocytes form, that is soon before hatching.

Clearly, if adoption of genetic information from DNA can occur but is a rare event involving substitution for native DNA in the chromosome structure, then it will be easier to detect in systems in which the target cells are homozygous recessive and the DNA comes from a homozygous dominant source. Hence our target cells were $d / d$ in genotype and were those forming the environment in which melanoblasts live-primarily the skin. The melanocyte complement of our animals was the indicator of the genetic status of the treated cells.

\section{THE SOURCES AND PREPARATION OF THE DNA}

In our experiments and their controls we have used DNA extracted from testis or blood of Ambystoma mexicanum and blood of cockerel. For the major experiments we used testicular DNA because tissue cells might conceivably lose or discard genetic material no longer necessary to their specialised functions, but germ-line cells may be presumed, almost by definition, to have an intact complement of genetic information. Wherever possible testes of black animals were taken from those known from breeding experience to be $+/+$ or almost certain to be so because wild caught. In our early work we had occasionally to use donors which may have been heterozygous.

DNA was prepared from cockerel blood and from the testes of white axolotls $(d / d)$ for use in control experiments. 
The DNA was extracted by the method of Zamenhof (1958) which avoids conditions known to cause loss of transforming activity in bacterial DNA (Zamenhof, et al., 1953). The concentrations of the final preparations were measured by UV absorption or colorimetrically (Geriotti, 1952). Viscosity measurements suggest a molecular weight of about six million for our final preparations. Yields and concentrations for the preparations used in some of our major experiments are given in table $\mathrm{I}$.

The DNA extracts were stored cold $\left(0-4^{\circ} \mathrm{C}\right.$.) in the final saline-citrate of the preparative process $\left(0 \cdot \mathrm{I}_{4} \mathrm{M} \mathrm{NaCl} / 0 \cdot{ }_{5} \mathrm{M}\right.$ Na-citrate). They were usually administered to target cells within days of preparation,

\section{TABLE I}

Typical DNA preparations and the quantities of DNA administered per injection unit

\begin{tabular}{|c|c|c|c|c|c|}
\hline $\begin{array}{l}\text { Preparation } \\
\text { no. }\end{array}$ & Source & $\begin{array}{c}\text { Tissue } \\
\text { quantity }\end{array}$ & $\begin{array}{l}\text { Yield of. } \\
\text { DNA in } \mathrm{mg} .\end{array}$ & $\begin{array}{c}\text { Concentration of } \\
\text { final solution in } \\
\mu \mathrm{g} . / \mathrm{ml} \text {. }\end{array}$ & $\begin{array}{l}\text { Estimated no. } \\
\text { of haploid sets in } \\
\text { I injection unit } \\
(0.2 \mu l .)^{*}\end{array}$ \\
\hline $\begin{array}{l}45 \\
4^{6} \\
3^{2} \mathrm{BL} \\
29 \mathrm{BL}\end{array}$ & $\begin{array}{l}+/+ \text { testis } \\
d / d \text { testis } \\
+/+ \text { blood } \\
\text { fowl blood }\end{array}$ & $\begin{array}{l}2.0 \mathrm{~g} . \dagger \\
2.7 \mathrm{~g} \cdot \dagger \\
2.0 \mathrm{ml} . \ddagger \\
6.0 \mathrm{ml} . \ddagger\end{array}$ & $\begin{array}{l}7 \cdot 4 \\
8 \cdot 2 \\
1 \cdot 3 \\
6 \cdot 5\end{array}$ & $\begin{array}{l}2400 \\
3600 \\
1150 \\
1300\end{array}$ & $\begin{array}{l}24,000\left(=0.4^{8} \mu \mathrm{g} .\right) \\
36,000(=0.72 \mu \mathrm{g} .) \\
\text { I } 1,500(=0.23 \mu \mathrm{g} .) \\
\text { I } 3,000(=0.26 \mu \mathrm{g} .)\end{array}$ \\
\hline
\end{tabular}

* Assuming $20 \mu \mu \mathrm{g}$. DNA per haploid nucleus.

$\dagger$ Wet weight.

$\ddagger$ Packed red cell volume.

but in some cases DNA of up to I2 weeks old was used. Bacterial transforming activity would not be greatly reduced by many months' storage of this kind.

In a few experiments heat-denatured DNA was tested because it is known (see Bollum, I 963 ) that such DNA functions more efficiently in the replicative DNA polymerase reaction. Denaturation was by the method of Bollum (1959); a DNA solution of $1400 \mu \mathrm{g} . / \mathrm{ml}$. in saline-citrate solution was heated slowly to $c .98^{\circ} \mathrm{C}$., kept at this temperature for to min. and then cooled rapidly to $c .20 \mathrm{C}$.

In other experiments DN protein was injected instead of DNA, partly because its uptake by embryonic cells might be expected to be more rapid. The nucleoprotein precipitate of a partial Zamenhof extraction was resuspended by homogenising in $2 \mathrm{M} \mathrm{NaCl}$-citrate and left in the cold for Io hrs. It was then centrifuged for $90 \mathrm{~min}$. at 25,000 g., the supernatant removed and the DN protein precipitated with ethanol and resuspended in $\mathrm{I} M \mathrm{NaCl} / \mathrm{o}_{1}{ }_{5} \mathrm{M}$ Na-citrate.

\section{DESIGN AND EXECUTION OF THE EXPERIMENTS}

A number of preliminary experiments were performed in which systems of $d / d$ cells received " black" DNA and were later compared 
with untreated cells. Thus, fertilised but as yet uncleaved eggs were injected intracellularly, blastulæ into the blastocoel, and tail-bud embryos beneath the presumptive epidermis of the flank. The blastema cells of limb and tail regenerates of older larvæ were treated by injection directly into the blastema and by simultaneous intraperitoneal injection into their bearers. Eggs and embryos were scored at the first opportunity, i.e. when the two phenotypes can be diagnosed by inspection, and at intervals thereafter. Blastemata were scored by examination of the completed regenerate. Scoring in the first instance involved a comparison with uninjected normal control siblings. In some series the number of survivors was small but in no case, except when tail-bud embryos were treated, was there evidence of abnormal pigmentation in the treated animals. Table 2 summarises all the experimental series.

TABLE 2

Summary of d/d target systems to which $+1+D \mathcal{N A}$ has been administered

\begin{tabular}{|c|c|c|c|}
\hline Target cells & $\begin{array}{c}\text { No. of animals } \\
\text { treated }\end{array}$ & $\begin{array}{l}\text { No. surviving } \\
\text { to scoring age }\end{array}$ & Result \\
\hline $\begin{array}{l}\text { o } \cdot \text { I cell stage } . \\
\text { Blastulæ }: \\
\text { Tail-bud embryos } \\
\text { Tail regeneration blastema } \\
\text { Limb regeneration . }\end{array}$ & $\begin{array}{r}650 \\
400 \\
1015 \\
19 \\
10\end{array}$ & $\begin{array}{r}41 \\
155 \\
477 \\
16 \\
9\end{array}$ & $\begin{array}{l}\text { No phenotypic change } \\
\text { No phenotypic change } \\
\text { Some phenotypic change } \\
\text { No phenotypic change } \\
\text { No phenotypic change }\end{array}$ \\
\hline
\end{tabular}

However, not only did our early experiments with tail-bud embryos seem to show a shift in phenotype towards that of the DNA donor, but they also gave a better survival than did embryos injected at younger ages. Hence we concentrated most of our subsequent efforts on embryos of this age.

There were, furthermore, two theoretical reasons for thinking them especially suitable targets. The tail-bud embryo of the urodele does not yet owe its pigmentation to melanocytes which, as melanoblasts of neural crest origin, have only just begun their ventral migration beneath the ectoderm (presumptive epidermis). Thus in our system this stage is the first at which the $d / d$ genotype can be expressed by failure of migration to occur. To inject DNA at this stage is therefore to provide genetic information which could, in principle, be used at once, without necessarily demanding full incorporation of the foreign DNA into the somatic cell's genome. Furthermore it so happens that the most probable site of the primordial germ cells of the tail-bud urodele is fairly close to the most convenient site of injection for somatic effects. Long surviving experimental animals could therefore be reared for breeding to test for true, transmissible, incorporation of administered DNA. 
In these experiments a small volume of DNA solution, either 0.2 or $0.4 \mu \mathrm{l}$. was injected unilaterally beneath the dorso-lateral flank ectoderm. The inoculum usually formed a bleb (fig. I) which overlapped presumptive dorsal (pigmented) and lateral (unpigmented) ar eas of the flank. In favourable cases such blebs disappeared after several hours, leaving no visible trace of their existence. Occasionally they burst, and when this happened the embryo was discarded. However, there were cases, especially after DN protein injection, in which the site of unburst blebs remained visible as a persistent puckered area of skin.

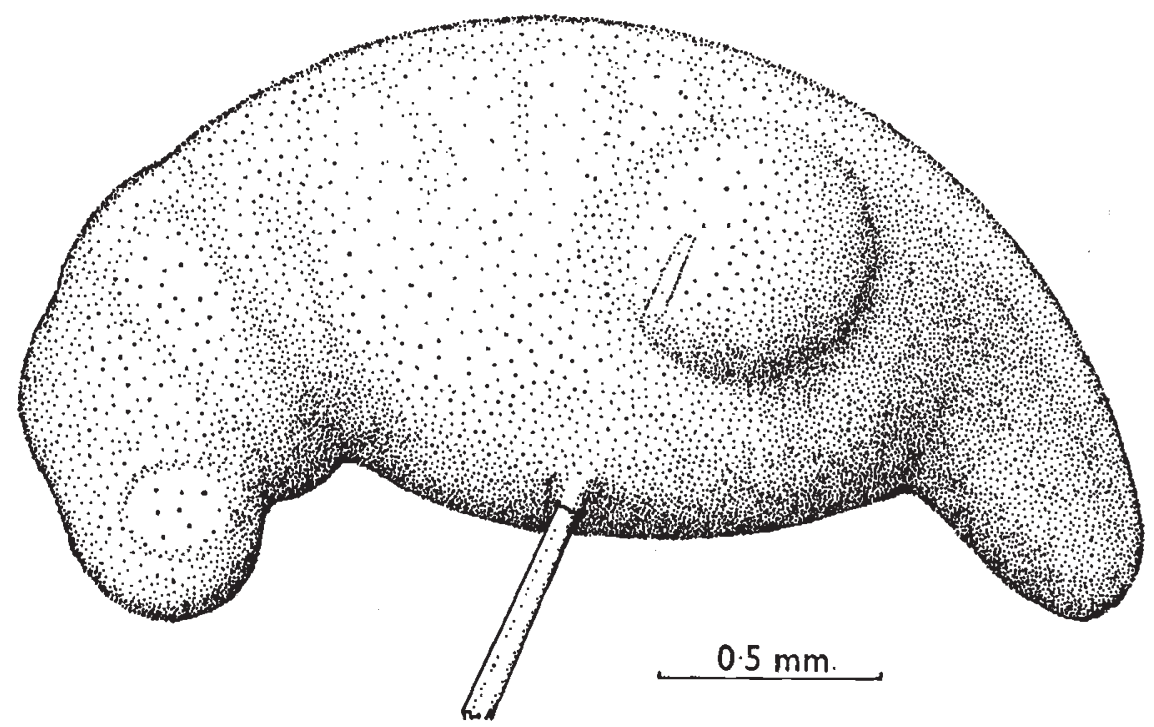

FIG. 1.-Tail-bud stage embryo of $A$. mexicanum to show mode of administration of DNA solution with formation of a sub-ectodermal bleb.

It is known from transplantation experiments that if the area of ectoderm thus directly exposed to DNA were removed from a $d / d$ animal and replaced by either $+/ d$ or $+/+$ ectoderm, then the graft would come to be richly populated by fully developed melanocytes (though of host, or $d / d$, constitution). This experiment thus asks whether $+1+$ DNA with $d / d$ cells are equivalent to $+1+$ or $+/ d$ cells on a simple developmental criterion. Scoring can be carried out at the time of first appearance of melanocytes (fig. 2a) and later (fig. $2 b$ ).

In our first experiments comparisons were made between injected and uninjected sides of experimental animals and between these and uninjected normal $d / d$ controls. We chose an area of the flank which in $d / d$ animals has a low population of melanocytes and which would include most of the cellular descendants of the treated cells (see fig. 2) and counted the number of melanocytes lying wholly within it. Later, when it appeared that our experimental animals were scoring highly, we added experimental controls into which $d / d$ DNA was injected. 
When these seemed to indicate that the concentration of DNA was the significant factor affecting our scores, we tested bird blood DNA of differing concentrations in the same way. In nearly all cases a single

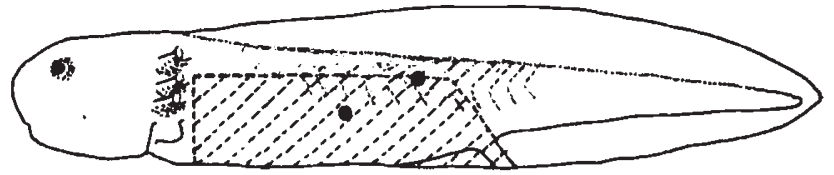

a.

$11.0 \mathrm{~cm}$

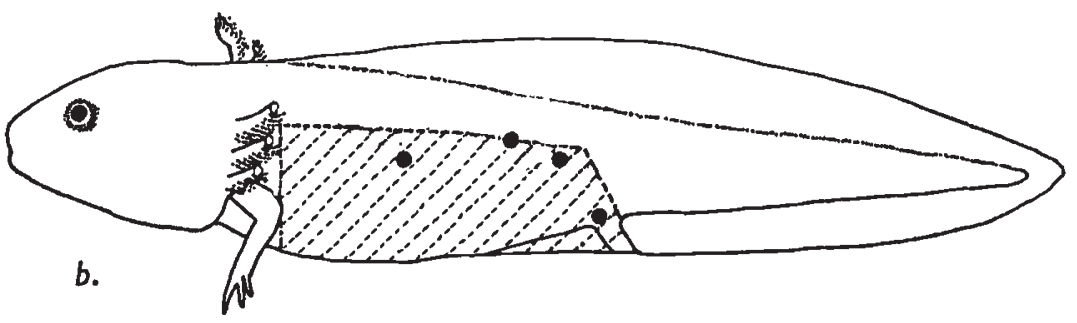

Fig. 2. - The area scored in larvæ shown shaded. It is bounded ventrally by the midventral line, posteriorly by the posterior margin of the anal tube (and its projection dorsally), dorsally by the line of flexure of the myotomes and anteriorly by the level of the posterior margin of the 2nd post-brachial segment.

2a. - Larva at stage of first scoring. The score as shown is $\mathrm{I}$, i.e. one melanocyte (here represented schematically as circular) lies wholly within the scoring area.

$2 b$. - Larva at 3 weeks post-tailbud. Score as shown is 3 .

experiment was defined by its use of eggs from one spawning of a single pair of adults for both normal controls and injected animals.

\section{RESULTS}

We shall report in detail only the results of the inoculation of tail-bud embryos upon the pigmentation of the region of injection some three weeks later. As is shown in table 3 normal controls have generally a mean score of about $\mathrm{I} \cdot \mathrm{O}$ on each side of the body. The scores tend to be symmetrical in each clutch of siblings, though there is inter-clutch variation. From the age of the earliest possible scoring (about seven days post-tailbud) for several weeks there is little change in score, though it often reaches a first peak at about three weeks posttailbud. The later falling off due to melanocyte death is slight, but we have chosen to illustrate our results from scores taken at or near twenty-one days after the injection stage.

In nearly all the experiments in which $+1+$ DNA was injected the mean melanocyte score of the injected side was higher than that of the normal controls, and there was further a tendency for the contralateral side to score high as well (table 4). Yet although in each experiment a large contribution to the raising of the mean was made by relatively few animals, no individual showed even a small area of 
skin which was as heavily pigmented as that of a normal black larva would be. This, in itself, did not discourage the view that adoption of specific genetic information was occurring, since if it were an

TABLE 3

Bilateral symmetry of scores in normal d/d controls

\begin{tabular}{|c|c|c|c|c|}
\hline & & & \multicolumn{2}{|c|}{ Mean score } \\
\cline { 4 - 5 } Group & $\begin{array}{c}\text { Post-tailbud } \\
\text { age in days }\end{array}$ & No. scored & \multicolumn{2}{|c|}{} \\
\cline { 4 - 5 } & & & LHS & RHS \\
\hline & & & & \\
$\mathrm{a}$ & 22 & 29 & 0.75 & 0.9 \\
$\mathrm{~b}$ & 22 & $3 \mathrm{I}$ & 0.85 & 0.58 \\
$\mathrm{c}$ & 22 & 35 & 0.15 & 0.03 \\
$\mathrm{~d}$ & 22 & 22 & 0.67 & 0.34 \\
$\mathrm{e}$ & 26 & $2 \mathrm{I}$ & $\mathrm{I} \cdot 80$ & $\mathrm{I} \cdot 58$ \\
$\mathrm{f}$ & $2 \mathrm{I}$ & 25 & 0.50 & 0.60 \\
$\mathrm{~g}$ & 0 & 54 & $\ldots$ & $\ldots$ \\
$\mathrm{g}$ & 7 & 49 & 0.47 & $0.5 \mathrm{I}$ \\
$\mathrm{g}$ & 20 & 48 & 0.58 & 0.56 \\
$\mathrm{~g}$ & 34 & 23 & 0.26 & 0.43 \\
\hline
\end{tabular}

The mean melanocyte counts on either side of several normal control groups to show bilateral symmetry of scores. Scores are given for groups a-f at one age only. For group $g$ the scores are given for several ages.

TABLE 4

\begin{tabular}{|c|c|c|c|c|}
\hline Group & $\begin{array}{c}\text { No. of } \\
\text { animals } \\
\text { scored }\end{array}$ & $\begin{array}{c}\text { Area } \\
\text { scored }\end{array}$ & $\begin{array}{l}\text { Mean score } \\
\text { at } c .2 \text { days } \\
\text { post-tailbud } \\
\text { and S.E. }\end{array}$ & No. of scores over 4 \\
\hline $\begin{array}{l}\text { Normal controls } \\
\text { Experimental controls injected } \\
\text { with } d / d \text { DNA } \\
\text { Experimental injected with } \\
\quad+1+\text { DN } \Lambda\end{array}$ & 377 & $\begin{array}{l}\left\{\begin{array}{l}\text { LHS } \\
\text { RHS }\end{array}\right. \\
\left\{\begin{array}{l}\text { IS } \\
\text { US }\end{array}\right. \\
\left\{\begin{array}{l}\text { IS } \\
\text { US }\end{array}\right.\end{array}$ & $\begin{array}{l}I \cdot 06 \\
O \cdot 88 \\
2 \cdot 75 \\
I \cdot 70 \\
I \cdot 8 \\
I \cdot 025\end{array}$ & $\begin{array}{c}7(3.5 \text { per cent.) } \\
5 \text { (2.5 per cent.) } \\
41 \text { (19.5 per cent.) } \\
\text { I } 7(8.1 \text { per cent.) } \\
31 \text { ( }(8.2 \text { per cent.) } \\
\text { I6 }(4.2 \text { per cent.) }\end{array}$ \\
\hline $\begin{array}{l}\text { Normal controls } \\
\text { Experimental controls injected } \\
\text { with } d / d \text { DNA } \\
\text { Experimental injected with } \\
\quad+/+ \text { DNA }\end{array}$ & $\begin{array}{l}4^{8} \\
6 o\end{array}$ & 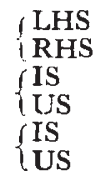 & $\begin{array}{l}0 \cdot 58 \pm 0 \cdot 12 \\
0 \cdot 56 \pm 0 \cdot 11 \\
6 \cdot 0 \pm 0 \cdot 91 \\
2 \cdot 1 \pm 0 \cdot 35 \\
2 \cdot 25 \pm 0 \cdot 39 \\
I \cdot 06 \pm 0 \cdot 15\end{array}$ & $\begin{array}{l}\text { o } \\
\text { o } \\
29 \text { ( } 48 \text { per cent.) } \\
\text { II }(18 \text { per cent. }) \\
6 \text { ( } 9.8 \text { per cent.) } \\
2 \text { ( } 3.3 \text { per cent. })\end{array}$ \\
\hline
\end{tabular}

The effects of injecting $+1+$ and $d / d$ DNA into tail-bud embryos upon the melanocyte counts three weeks later. IS $=$ injected side; $U S=$ uninjected side. The summed results of 8 experiments are given above and the data from one experiment are given below.

uncommon and a random event and only between I per cent. and 10 per cent. of the treated cells were affected, just such an increase in melanocyte numbers would be predicted. 
However, experimental controls injected with $d / d$ DNA achieved scores that were, in practice, higher still (table 4). This effectively removed any temptation to regard the results with $+1+$ DNA as genetically specific. The explanation probably springs from the fact that in all our earlier experiments our DNA solutions were used at the maximum concentration yielded by their preparation. It so happened that most of the $d / d$ DNA solutions were more concentrated than those

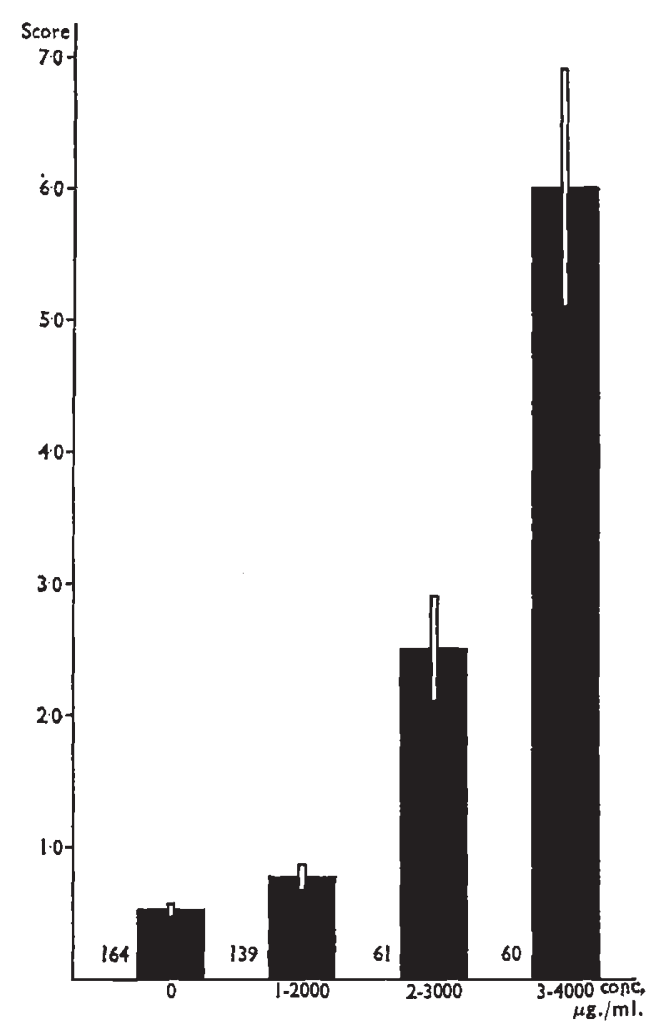

FIG. 3.- Melanocyte score as a function of the concentration of DNA administered to tail-bud embryos 3 weeks earlier. Main column heights give mean score on injected side (both sides in case of uninjected controls). Slender columns give twice the S.E. of the means. Total number of observations in each group is given to the left of each column.

of $+1+$ DNA. That concentration, rather than genetic provenance, is the crucial factor is shown in fig. 3 .

While these experiments provide no evidence for the transfer of genetic information they do not tell against the idea that DNA as such can cause a slight local shift of the $d / d$ phenotype towards the wildtype. Experiments performed with heterologous (fowl) DNA lent some support to this idea (see table 5), but that the integrity of the double helix is not necessary for this effect is shown by significant increases in score obtained by injections of heat-denatured DNA. On the other hand the highest mean scores we ever obtained were after 
injection with DN protein. Since the DN protein solutions appeared to be more viscous than the DNA ones it seems possible that the viscosity rather than the chemical or other physical properties, of the nucleic

TABLE 5

\begin{tabular}{|c|c|c|c|}
\hline Group & Nos. & Area scored & $\begin{array}{c}\text { Mean score at } \\
20 \text { or } 21 \text { days } \\
\text { post-tailbud and S.E. }\end{array}$ \\
\hline $\begin{array}{l}\text { Normal controls } \cdot \dot{ } \cdot \dot{ } \\
\text { Denatured } d / d \text { DNA (1350 } \mu \text { g.ml.) }\end{array}$ & $\begin{array}{l}34 \\
17\end{array}$ & $\begin{array}{l}\text { LHS }+ \text { RHS } \\
\quad\left\{\begin{array}{l}\text { IS } \\
\text { US }\end{array}\right.\end{array}$ & $\begin{array}{l}0.44 \pm 0.11 \\
0.88 \pm 0.31 \\
0.83 \pm 0.23\end{array}$ \\
\hline $\begin{array}{l}\text { Denatured }+/+ \text { DNA } \\
\quad\left(115^{\circ} \mu \mathrm{g} \cdot \mathrm{ml} .\right)\end{array}$ & 18 & $\left\{\begin{array}{l}\text { IS } \\
\text { US }\end{array}\right.$ & $\begin{array}{l}1 \cdot 39 \pm 0 \cdot 30 \\
1 \cdot 06 \pm 0 \cdot 27\end{array}$ \\
\hline $\begin{array}{l}\text { Normal controls } . \\
\text { Fowl blood DNA }(3700 \mu \mathrm{g} \cdot \mathrm{ml} .)\end{array}$ & $\begin{array}{l}11 \\
19\end{array}$ & 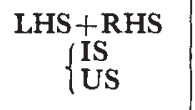 & $\begin{array}{l}1 \cdot 77 \pm 0 \cdot 33 \\
3 \cdot 60 \pm 0 \cdot 63 \\
3 \cdot 95 \pm 0 \cdot 68\end{array}$ \\
\hline $\begin{array}{l}\text { Normal controls } \\
d / d \mathrm{DN} \text { protein }(900 \mu \mathrm{g} \cdot \mathrm{ml} .) \\
+/+\mathrm{DN} \text { protein }\left(235^{\circ} \mu \mathrm{g} \cdot \mathrm{ml} .\right)\end{array}$ & $\begin{array}{l}10 \\
24 \\
24\end{array}$ & 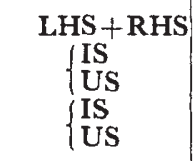 & $\begin{array}{r}0.5 \pm 0.41 \\
3 \cdot 25 \pm 0.85 \\
1 \cdot 79 \pm 0.85 \\
7 \cdot 9 \pm 1 \cdot 49 \\
3 \cdot 87 \pm 0.39\end{array}$ \\
\hline
\end{tabular}

Effect of injection of substances other than normal homologous DNA into tail-bud embryos upon melanocyte score three weeks later. IS = injected side; US $=$ uninjected side.

acid component of our inocula was effective. Experiments with other macromolecules, including different RNAs, are in progress and may allow us to settle this point.

\section{DISCUSSION}

We are well aware of the caution that must qualify the obvious assumption that no transfer of information can occur in our system. We do feel entitled to conclude, however, that very few, if any, of the somatic cells exposed to exogenous DNA incorporated that part of it associated with the $d$ locus. Incorporation of the kind occurring during bacterial transformation is thus, at best, the exception rather than the rule. Our experience here contrasts with that of Benoit and his colleagues whose administration of homologous DNA to ducks was followed by changes which, if interpreted as transformation, suggested a surprising degree of susceptibility in the cells exposed.

We cannot, of course, exclude the possibility that our inocula are mutagenic, and that the $d$ locus saw a sufficient number of back-mutations to cause the effects obtained. We ourselves regard this as a priori unlikely, but will be forced to reconsider our views if any $d / d$ animals injected with materials other than + DNA give gametes which prove to be + . 
Our results argue equally, or perhaps more strongly, against a readiness on the part of the target cells to accept genetic information from DNA by methods that fall short of the complete integration of the administered material into the chromosomal apparatus of the cell. Viral-like infection of our cells by a DNA capable both of replicating and of yielding up its information does not appear to have occurred. If this were a biologically possible event it could well be a more probable one than true transformation, which in higher organisms might demand the most complicated co-operation from the chromosomal apparatus. A final possibility is that homologous DNA administered to metazoan cells might fail to replicate, but nevertheless offer information for a brief period of time and thus temporarily control the kind of synthesis undertaken by the target cell. Such hormone-like behaviour could have been revealed by our material since administration took place at a time of known gene activity. That it was not revealed is the final demonstration of our failure to find specific biological activity of extracted DNA in our system.

\section{SUMMARY}

I. An attempt to provoke genetic transformation of embryonic amphibian cells by the administration of homologous, genetically labelled, DNA revealed no evidence that genetic incorporation or other possible forms of information transfer occurred.

2. A change of phenotype of treated animals in the predicted direction proved to be a non-specific response to the administration of high concentrations of DNA.

Acknowledgments.-This work has been made possible by the generosity of the Nuffield Foundation, and owes much to the encouragement of Dr P. B. Medawar, in whose former Department at University College London it was begun. We gratefully acknowledge the assistance of Mrs J. Hunt and Mr A. Langi.

\section{REFERENCES}

ASTAUROV, B. L., BEDNIAKOVA, T. A., GINSBURG, S. L., ZBARSKY, I. B., AND RAMENSKAYA, s. P. 196o. An attempt to induce hereditary changes in the silkworm (Bombyx mori L.) by means of DNA injection from a genetically different strain. Dok. Acad. Nauk r34, 449-452.

BALTZER, F. 1947. Weitere Beobachtungen an merogenischen Bastarden der schwarzen und weissen Axolotlrasse. Rev. suisse Zool., 54, 26o-269.

BEARN, J. S., AND KIRBY, K. S. 1959. Failure of DNA to produce pigment changes in the albino rat. Exp. Cell Res., I7, 547-549

beatty, R. A., AND billet, F. s. I961. Genetics of Gametes. VI. Attempted genetic transformation in the Rabbit. Proc. roy. Soc. Edin., 68, 83-9o.

BENOIT, J., LEROY, P., VENDRELy, C., AND VENDREly, R. 195\%. Des mutations somatiques dirigées sont-elles possibles chez les Oiseaux. C.R. Acad.Sci., 244, 2320-2321.

Benoit, J., Leroy, P., Vendrely, c., AND vendrely, R. 1958. Phenotype du bec des Canetons provenant de première et deuxième générations des Canard Pekin antérieurement traités à l'ADN de Canard Khaki Campbell. C.R. Acad. Sci., 247, 1049-1052 
BENOIT, J., LEROY, P., VENDRELy, G., AND VENDRELy, R. 1960. Experiments on Pekin ducks treated with DNA from Khaki Campbell ducks. Trans. N.Y. Acad. Sci., 22, 494-503.

Bollum, F. J. 1959. Thermal conversion of non-primary deoxyribonucleic acid primer. 7. biol. Chem., 234, 2733-2734.

Bollum, F. J. 1963. "Primer" in DNA polymerase reactions. Progress in Nucleic Acid Research, I, I-26.

Cerjotti, G. 1952. A micro-method for the determination of DNA. 7. biol. Chem., $198,297-303$.

CHURCH, G. 1955. The viability and pigmentation of axolotl chimeras. F. Morph., $96,565-577$.

DALTON, H. C. 1950. Inhibition of chromatoblast migration as a factor in the development of genetic differences in pigmentation in white and black axolotls. 7. exp. Zool., $115,151-174$.

DUSHANE, G. P. I939. Role of embryonic ectoderm and mesoderm in amphibian pigment production. F. exp. Zool. 82, 192-215.

FAHMY, O. s., AND FAMHY, M. J. 1961. Induction of mutation by deoxyribonucleir acid in Drosophila melanogaster. Nature, Lond., 191, 776-779.

haECKER, v. 1907. Über Mendelschen Vererbung bei Axolotln. Zool. Anz., 3r, 99-102.

HARRISON, R. G. 1935. Heteroplastic grafting in embryology. The Harvey Lectures, 1933-34, 116-157.

KRAUS, L. M. (1961). Formation of different hæmoglobins in tissue culture of human bone marrow treated with human deoxyribonucleic acid. Nature, Lond., 192, 1055-1057.

SZYBALSKA, ELIZABETH H., AND SZYBALSK1, W. 1962. Genetics of human cell lines. IV. DNA mediated heritable transformation of a biochemical trait. Proc. Nat. Acad. Sci. (U.S.A.), $4^{8,}, 2026$.

zamenhof, s. 1958. Deoxyribonucleic Acid; in "Biochemical Preparations". (Ed. Westling, C. S.), Wiley, London, 6, 8-12.

ZAMENHOF, S., ALEXANDER, M. E., AND LEIDY, G. 1953. Studies on the chemistry of the transforming activity of DNA-Resistance to physical and chemical agents. 7. $\exp$. Med., $98,373-397$. 